\title{
Determinant Independence and Objectivity of Internal Auditors in Indonesian Government Organizations
}

\section{Febrina Kurniawati ${ }^{1}$, Sutaryo ${ }^{1}$, Asa Prima Putra Karunia ${ }^{1}$, Payamta ${ }^{1}$, and Supriyono²}

${ }^{1}$ Universitas Negeri Sebelas Maret, Jl. Ir. Sutami No. 36A, Jebres, Kota Surakarta, Jawa Tengah 57126, Indonesia

${ }^{2}$ Universitas Islam Negeri Syarif Hidayatullah, Jl. Ir. H. Djuanda No. 95, Ciputat, Kota Tangerang Selatan, Banten 15412, Indonesia

\section{Abstract}

We examine the effects of auditor's competence, auditor-auditee relationship, professional identification and top-management support toward internal auditors' independence (Ahmad and Taylor, 2009) and objectivity (Muqattash, 2011) in

Corresponding Author:

Supriyono

supri1101.sy@gmail.com

Received: 25 February 2018

Accepted: 26 May 2018

Published: 26 June 2018

Publishing services provided by

Knowledge $\mathrm{E}$

(c) Febrina Kurniawati et al. This article is distributed under the

terms of the Creative Commons

Attribution License, which

permits unrestricted use and

redistribution provided that the

original author and source are credited.

Selection and Peer-review under the responsibility of the ICIFEB Conference Committee. the Ministry of Finance and the Ministry of Religious Affairs. Responses from questionnaires were collected from 204 respondents of internal auditors in both the ministries. Using multiple linear regression models, we found that auditors' competence and auditor-auditee relationship have a significant effect toward both the independence and objectivity of the auditors, while top-management support only affects the auditors' objectivity. The study shows different results for each ministry. Only auditor-auditee relationship affects the independence in both the ministries, and only auditor's competence affects the objectivity in both the ministries. Thus, we agree that auditors' competence and auditor-auditee relationship are two most important factors in determining both the independence and objectivity of internal auditors in Indonesian government entities.

Keywords: independence, objectivity, internal auditors, government entity, competence, Indonesia

\section{Introduction}

Apparently, government institution performances have withdrawn public's attention and become a current issue. Back to 20 years ago, the public was not aware of government programs such as government activities until the result of the programs. However, since the transparency of information is easy to access nowadays, today's 
society is equipped and informed to question government's performance, such as the government's budget plans on projects and how the government plans to exercise the income from tax and other sources of income. Moreover, this is the right of the citizens since taxes and other sources of income are collected directly and indirectly from them. It is a responsibility of every government institution to show to the public their accountability report through audited financial report as a potent source of public information.

There is a slight change of orientation in conducting government activities along with the issuance of Law No. 17 of 2003 on State Finance, Law No. 1 of 2004 concerning State Treasury and Law No. 15 of 2004 concerning the State Financial Management and Accountability Audit. According to these laws, the government should be conducted with the principle of result-oriented, rather than input-oriented (budget).

With the aforementioned conditions, auditors, both external and internal, have a significant role in providing publics' need of information regarding the financial activities of government, such as in the central government, the level of ministry and local government. In providing that information, there are several characteristics that must be accomplished by both internal and external auditors, including independence and objectivity. Furthermore, independence and objectivity are two of the basic assumptions to represent the value and credibility of auditor's service. Auditor's independence is the cornerstone of audit profession [27].

Auditors should comply with two elements of independence, which are independence in mind and independence in appearance. The challenges on internal auditors is to appear independent since their clients are mostly (or absolutely) the organization where they are working, not to mention they are in a different department and they are working within the organization. Internal auditor's unique characteristics, in which they provide both assurance service within the organization and consultancy service to the managers, have become a consequential debate as internal auditors are easy to be placed in a conflict situation [32]. There has been quite an amount of research regarding the independence and objectivity of auditors, but most of them took external auditors as objects. However, for an internal auditor, mainly the internal auditor for Government Organizations, such researches are rarely conducted.

Based on the Ministry of Domestic Affairs' website, on May 26, 2017, Corruption Eradication Commission (KPK) set a meeting with the Ministry of Domestic Affairs to discuss a re-enforcement of the roles of Government Internal Supervisory Apparatus (APIP) in eradicating corruption. According to KPK, APIP's role to corruption eradication is still low because currently, the authority of APIP is under their own organization 
instead of being an independent entity. The main issue brought by the KPK about the re-enforcement of APIP is about their independence. The Ministry of Domestic Affairs is asked to redesign the organization of APIP to be more independent. Other than that, re-enforcement of the human resource and budget sufficiency also need to be the main concern of this program. To increase the quality of the APIP in eradicating corruption, the government must first know the factors that affect independence and objectivity of the auditors so that they can design a strategy to re-enforce the human resource, in this case, the internal auditors.

According to Government Regulation No. 60 of Year 2008 about Government Internal Supervisory System (SPIP), the purpose of the SPIP is to provide adequate assurance for the accomplishment of efficiency and effectiveness of government purposes, the reliability of the financial report, the security of state assets and the adherence to legislation. The roles of APIP are as follows: (a) provide adequate assurance of the adherence, economics, efficiency and effectiveness of the accomplishment of government entities' tasks and functions; (b) provide early warning and improve the effectiveness of risk management in the execution of government entities' tasks and functions; (c) maintain and improve the quality of good governance. The present condition shows that there is still a gap between the purpose that should be accomplished by APIP and the reality. There are still many fraud and errors in government financial statement, corruptions and embezzlement.

Even though the financial report of the Central Government was predicated unqualified in 2016, there are 14 ministries that have not accomplished the same predicate for their financial statements. Even worse, six of them got disclaimers from the Audit Board of the Republic of Indonesia (BPK); they are Ministry of Marine and Fisheries, National Commission on Human Rights, Ministry of Youth and Sports, TVRI, Marine Security Agency and Agency of Creative Economy. The other eight ministries have qualified opinion from BPK; they are Ministry of Defense, Ministry of the Environment and Forestry, Ministry of Child and Women Empowerment, BKKBN, General Election Commission (KPU), Geo-spatial Information Agency, Provision of Government Goods and Services and RRI. In other words, there are 85 percent of ministries and institutes that get unqualified opinion. It is a good thing compared to the previous year when only 65 percent of the ministries and institutions got unqualified opinions. However, it is expected that every ministry/institution will get unqualified opinions in the next year.

The gaps between what is expected from APIP and the reality could be driven from the lack of independence and objectivity of the internal auditors. Chairman of KPK, 
Agus Rahardjo, said that one of the causes of ineffectiveness of corruption eradication and the enhancement of governance is independence problem of the APIP (KPK.go.id, May 2017). The other problems regarding APIP are the human-resource problems and budget problem. The human-resource problems include independence and objectivity of the auditors. Therefore, because there are still some problems in the implementation of SPIP, it is reasonable that the independence and objectivity of internal audit in government entities are worth to be researched.

Alexander and Hay (2013) use non-audit task as the independent variable for independence; Fan, Woodbine and Scully (2012) study the effect of auditor-client relationship, punishment system and ethical behavior toward audit independence; Romero (2010) finds the effect of auditor fee toward internal auditors' independence. Besides that, Bamber and lyer (2007) inspect professional identification and audit tenure in affecting auditor's objectivity; and Reynolds et al. (2004) use economic dependence as the independent variable toward objectivity. In this research, the author will examine five factors that could affect the independence and objectivity of internal auditors for the Ministry of Finance and the Ministry of Religious Affairs. Those factors, later to be called independent variables, are professional competence, auditor-auditee relationship, professional identification and top-management support.

The author focuses this research to two ministries in Indonesia: the Ministry of Finance and the Ministry of Religious Affairs. The choosing of the two ministries as the object of this study has several reasons behind. The Ministry of Finance is the chief financial officer of the government, and often considered as the role model for running government financial management. It is a fact that there are still many problems indicating its role as CFO, including the number of litigation cases that include the Ministry of Finance, and this leads to the spotlight given from the public for this ministry. There are also several cases undergone by the Ministry of Religious Affairs that lead to public skepticism against this ministry such as embezzlement of Hajj fund and corruption in the procurement of Qurans.

Professional competence is one of the most important factors in conducting audit job. Auditing is a profession that no one outside the accounting field can do. Professional competence might as well be the indicator of auditor's quality, if he is competent in his job, then his job must be qualified. The real question is, does their competence really support their understanding and implementation of independence and objectivity? Independence and objectivity are more of professional ethics rather than competence, so we need to see the correlation between professional competence toward internal auditors' independence and objectivity. 
Professional identification is how they see themselves as an auditor and how do they relate to the label 'auditor' that sticks to them. Being proud of their professional could be a positive spirit that could increase their job quality. The feeling of attachment toward their profession means that they have to understand the value and ethics of their profession. For auditors, it means that they will do their job independently and objectively.

Research conducted by Cohen and Sayag (2010) finds that top-management support has a very strong effect on the internal audit effectiveness and is a very important factor for the success of it. Improving internal auditors' proficiency through education and training or providing internal auditor with proper facilities and sufficient budget are some examples of how top-management support could increase the effectiveness of internal audit.

The relationship between internal auditor and auditee is somehow unique, on account of their client's position that is in the same organization as them. This kind of position could threaten their independence and objectivity in doing audit job. The relationship quality between auditor and auditee could be seen by the absence of conflict of interest between them. A good relationship between auditor and auditee does not mean that they often meet outside the work or they have a personal relationship other than auditor-client relationship. It means that they could keep their independence, whether in fact or in appearance, so that they could also maintain their objectivity in doing their job.

\section{Literature Review and Hypothesis}

\subsection{Internal auditor in Indonesian government context}

Internal audit is an independent and objective activity in the form of assurance and consulting activities, designed to give value added and to enhance the operational quality of an organization (auditee). This activity helps the organization (auditee) to reach their goals with a systematic and organized approach to evaluate and improve the efficiency of risk-management process, control and public-sector governance [19]. Government internal audit standard is the criteria or minimum quality requirement to perform internal audit task, and compulsory for Indonesian government internal auditor (Finance and Development Supervisory Agency, 2013). 


\subsection{Independence}

AICPA (2006) defines audit independence as 'one's ability to act with integrity and exercise objectivity and professional skepticism. Therefore, independence is critical to promote ethical behavior and reliable financial reporting'. Hanifa (2009) in his research concluded that auditors could interpret independence through social interactions in three levels: micro (personal), Meso (organizational culture) and macro (political and socio-economic structure). Independence is in fact mostly related to micro level (personal), while Meso (organizational structure) has a particular association with independence in appearance. In macro level, socio-economic, politics, ideology and legal system could affect various kinds of independence and the meaning of auditor independence.

An auditor should be perceived to be independent both in fact and in appearance [29]. Cameran et al. (2005) stated that independence in fact portrays a state of mind that relates to integrity, objectivity and professional judgment, while Raiborn et al. (2006) conclude that the independence in appearance represents the external impression by the public about the auditor. Independence in appearance could be evaluated through independence in appearance level of auditor ([23], Ghost et al., 2005).

\subsection{Objectivity}

Mutchler (2001) defines objectivity as a state of mind that biases do not inappropriately affect assessments, judgments and decisions. Objectivity is at the heart of auditor's value to society to provide an unbiased opinion on the fairness of financial statements [21]. Arens, Elder and Beasly (2011, p.71) mention that auditors must not compromise in giving professional attestation because of biases, conflict of interest or because of influence of someone inappropriate.

Objectivity requires auditor not to differ their audit judgments toward their clients. Punishment regarding auditors' objectivity must be carried out at the whole level; individual, assignment, functional position and organization. The Code of Conduct of Indonesian Government Internal Auditor explains that internal supervision is an independent and objective assurance and consulting activity to give value added and to improve organization's operation. Hence, objectivity is an important aspect in determining whether or not can the audit task succeed.

In Ministerial Regulation of Ministry of Administrative and Bureaucratic No. PER/05/ M.PAN/03/2008 about the Audit Standard of Government Internal Supervisory Unit 
(APIP), it is mentioned that if independence or objectivity is compromised, whether in fact or in appearance, such disruption has to be reported to their superior. They are obliged to report regarding the existence and/or the interpretation about that the conflict of interests, dependence or biases. The auditor mentioned must be replaced with another auditor whose independence and objectivity are unquestioned.

Objectivity has a significant credit in an audit task. If auditor acts subjectively toward their client, the audit report would be either favorable or unfavorable to the auditee. In some cases, when objectivity is absent during the audit task, the report only consists of things that incriminate the auditee without proper evidence. This kind of audit quality will mislead the decision-making process because of information biases contained in the audit report.

\subsection{Professional competence toward independence and objectivity}

An audit must be carried out by a professional staff that has the necessary education, training, experience and professional qualifications to conduct the full range of audits required by its mandate (Al Twaijri, Brierly and Gwilian, 2003). Ma'ayan and Carmeli (2015) in their research mention that auditor capacity comprises professional skills, economic resources and behavior toward auditees. Auditors' professional skills are represented in their knowledge and experience ([13], OAG 2004), and professional credibility (Dies and Giroux 1992). Other than academic background, auditors also need to experience specific training in auditing field. Cohen and Sayag (2010) state that greater professional proficiency on the part of the internal auditors will be related to greater auditing effectiveness. Independence and objectivity are two main aspects that represent audit effectiveness. Therefore, professional competence should have a positive relationship toward both independence and objectivity of the internal audit.

$H_{1}$ : Professional competence has a positive effect toward government internal audit independence

$\mathrm{H}_{2}$ : Professional competence has a positive effect toward government internal audit objectivity 


\subsection{Professional identification toward independence and objectivity}

Mael and Ashforth (1992) define professional identification as 'the extent to which one defines him or herself in terms of the work he or she does and the prototypical characteristics ascribed to individuals who do that work'. Loi, Hang-yue and Foley (2004) suggest that professional identification is the main key that affects worker's job attitude. When auditors become identified with their profession of audit, they will associate the auditing profession into their identity. Professional identification could boost someone's professional self-esteem (Ashforth and Mael, 1989), it also provides an essential guide for attitudes and behaviors.

Auditors who identify audit as their profession tend to internalize the norms and values of their profession [7]. Consequently, auditor's professional identification will encourage their professional behavior and objectivity [21]. Independence and objectivity are two of the most important values that should be comprehended by auditors in general. Bamber and Iyer (2007) find that professional identification has a strong positive correlation toward auditors' objectivity. Hence, professional identification should affect positively the internal auditors' independence and objectivity.

H3: Professional identification has a positive effect toward government internal audit independence

H4: Professional identification has a positive effect toward government internal audit objectivity

\subsection{Auditor-auditee relationship toward independence and objectivity}

Auditors need a good cooperation from auditees because they are the main source of information that is important for auditors in order to do their work. As a vice versa, auditee needs auditor's assistance to let them know their wrongdoing and deficiencies in practicing their business. In Indonesian government case, internal auditor also performs to prepare the auditees before being audited by external auditor (in this case by the Audit Board of the Republic of Indonesia/BPK). A decent interaction between auditors and auditees that leads to auditees' positive attitude and suppresses the negativity toward auditing process is the key to auditees' motivation to engage in learning from the audit activity (Ma'ayan and Carmeli, 2015). A good relationship between 
auditor and auditee could be achieved when auditors do their job without being influenced by facilities or gratification given by the auditee. Mohamed and Habib (2013) have found that auditors-client relationship enhances the audit quality. This finding could lead us to a hypothesis that auditor-auditee relationship could enhance auditors' independence and objectivity.

H5: Auditor-auditee relationship has a positive effect toward government internal audit independence

H6: Auditor-auditee relationship has a positive effect toward government internal audit objectivity

\subsection{Top management support toward independence and objectivity}

Managerial support for audit could be defined as the involvement and commitment to success of the work by giving adequate attention and allocating needed support (Ma'ayan and Carmeli, 2015). The lack of top-management support to internal audit within an organization can cause ineffectiveness of internal audit, and this could be dangerous since top management's view could be contagious to the members of the organization. Such condition could appear from the mindset that internal audit is a burden to the organization, is costly and could act against the organization. Hence, it is not a surprising fact that top-management support plays a significant role in the work of internal audit.

There are several researches that find the role of management support in many successes of programs and process within an organization. Cohan and Sayag (2010) find that top-management support has a very strong correlation to internal audit effectiveness. The finding bespeaks that the top-management support's effect to the effectiveness of audit is very strong and consistent in both public and private sectors. They also state that top-management support is very crucial to the success of internal audit, and there is a strong indication that all other determinant factors of internal audit effectiveness could be derived from the top-management support, say, auditor's proficiency and career development. Based on this finding, a hypothesis can be developed that top-management support has positive effect toward the internal auditors' independence and objectivity.

H7: Top management support has a positive effect toward government internal audit independence 
H8: Top management support has a positive effect toward government internal audit objectivity

\section{Methodology}

\subsection{The participant}

TABle 1: Participant.

\begin{tabular}{|c|c|c|c|c|c|}
\hline \multirow[b]{2}{*}{ Annotation } & \multirow[b]{2}{*}{ Description } & \multicolumn{2}{|c|}{ Ministry of Finance } & \multicolumn{2}{|c|}{ Ministry of Religious Affairs } \\
\hline & & Number & $\%$ & Number & $\%$ \\
\hline \multirow[t]{2}{*}{ Gender } & Male & 116 & $85.05 \%$ & 52 & $78.79 \%$ \\
\hline & Female & 22 & $15.95 \%$ & 14 & $21.21 \%$ \\
\hline \multirow[t]{4}{*}{ Age } & $20-30$ & 70 & $50.72 \%$ & 14 & $21.21 \%$ \\
\hline & $31-40$ & 48 & $34.00 \%$ & 42 & $63.63 \%$ \\
\hline & $41-50$ & 8 & $5.80 \%$ & 6 & $9.09 \%$ \\
\hline & $51-60$ & 12 & $8.70 \%$ & 4 & $6.06 \%$ \\
\hline \multirow{4}{*}{$\begin{array}{l}\text { Professional } \\
\text { Tenure }\end{array}$} & $<4$ years & 18 & $13.04 \%$ & 20 & $30.30 \%$ \\
\hline & $4^{-8}$ years & 64 & $46.37 \%$ & 36 & $54.54 \%$ \\
\hline & 9-12 years & 36 & $26.08 \%$ & 2 & $3.03 \%$ \\
\hline & $>12$ years & 20 & $14.49 \%$ & 8 & $12.12 \%$ \\
\hline \multirow{2}{*}{$\begin{array}{l}\text { Auditor } \\
\text { Certification }\end{array}$} & Available & 122 & $88.41 \%$ & 66 & $100 \%$ \\
\hline & Not Available & 16 & $11.59 \%$ & 0 & $0 \%$ \\
\hline \multirow[t]{4}{*}{ Education } & D III & 28 & $20.29 \%$ & 6 & $9.09 \%$ \\
\hline & S1/DIV & 86 & $62.32 \%$ & 46 & $69.70 \%$ \\
\hline & S2 & 22 & $15.94 \%$ & 14 & $21.21 \%$ \\
\hline & $\mathrm{S}_{3}$ & 2 & $1.45 \%$ & 0 & $0 \%$ \\
\hline
\end{tabular}

The target population of this research is internal auditors in Indonesian government entities, particularly internal auditors in Ministry of Finance and Ministry of Religious Affairs. These two ministries were chosen because of some particular reasons. The Ministry of Finance was chosen because it is the Chief Financial Officer of Indonesian Government and is considered as the role model in every activity of government financial management. The Ministry of Religious Affairs, other than because of its 
organization size, has also withdrawn public attention about its performance and transparency of financial report due to several legal cases it has faced. There are total 416 internal auditors in Ministry of Finance and 249 internal auditors in Ministry of Religious Affairs. This means that the total population for this research is 665 internal auditors.

Questionnaires were mailed individually to internal auditors in these ministries by electronic mails. At the end of the collection process, we had 204 responses; 138 responses were from the Ministry of Finance and 66 responses were from the Ministry of Religious Affairs. Of all the respondents, 168 of them were male and 36 were female, and 85.3 percent of them aged less than 40 years. According to their tenure in their organization, 49.12 percent of all the respondents have been working in their organization for 4-8 years, and only 18.63 percent of them have been working for less than 4 years. More than 92 percent of the respondents have certification in audit field.

\subsection{Variable, operational and measurement}

In this research, the author uses two dependent variables, which are independence and objectivity of the internal auditor, and five independent variables, which are professional competence, professional identification, auditor-auditee relationship and topmanagement support. Questionnaires were distributed to internal auditors in the Ministry of Finance and the Ministry of Religious Affairs in Indonesia. There were 31 items question in the questionnaire, with Likert scale of 4 (strongly disagree-strongly agree). In most questions, strongly disagree is scored 1 and strongly agree is scored 4 . The summary for each variable can be seen in Table 2 .

\subsection{Data analysis method}

The analysis method in this research uses multivariate linear regression analysis to see the relationship between dependent and independent variables. The multivariate linear regression analysis can be written as the following equations:

$$
\begin{aligned}
& \text { IND }=\alpha+\beta 1 \text { COMP }+\beta 2 \text { PROFIDENT }+\beta 3 \text { AUDITEE }+\beta 4 \text { SUPPORT }+\varepsilon \\
& \text { OBJ }=\alpha+\beta 1 \text { COMP }+\beta 2 \text { PROFIDENT }+\beta 3 \text { AUDITEE }+\beta 4 \text { SUPPORT }+\varepsilon
\end{aligned}
$$

Notes:

$$
\begin{aligned}
& \text { IND = Internal Auditors Independence } \\
& \mathrm{OBJ}=\text { Internal Auditors Objectivity }
\end{aligned}
$$


TABLE 2: Variables.

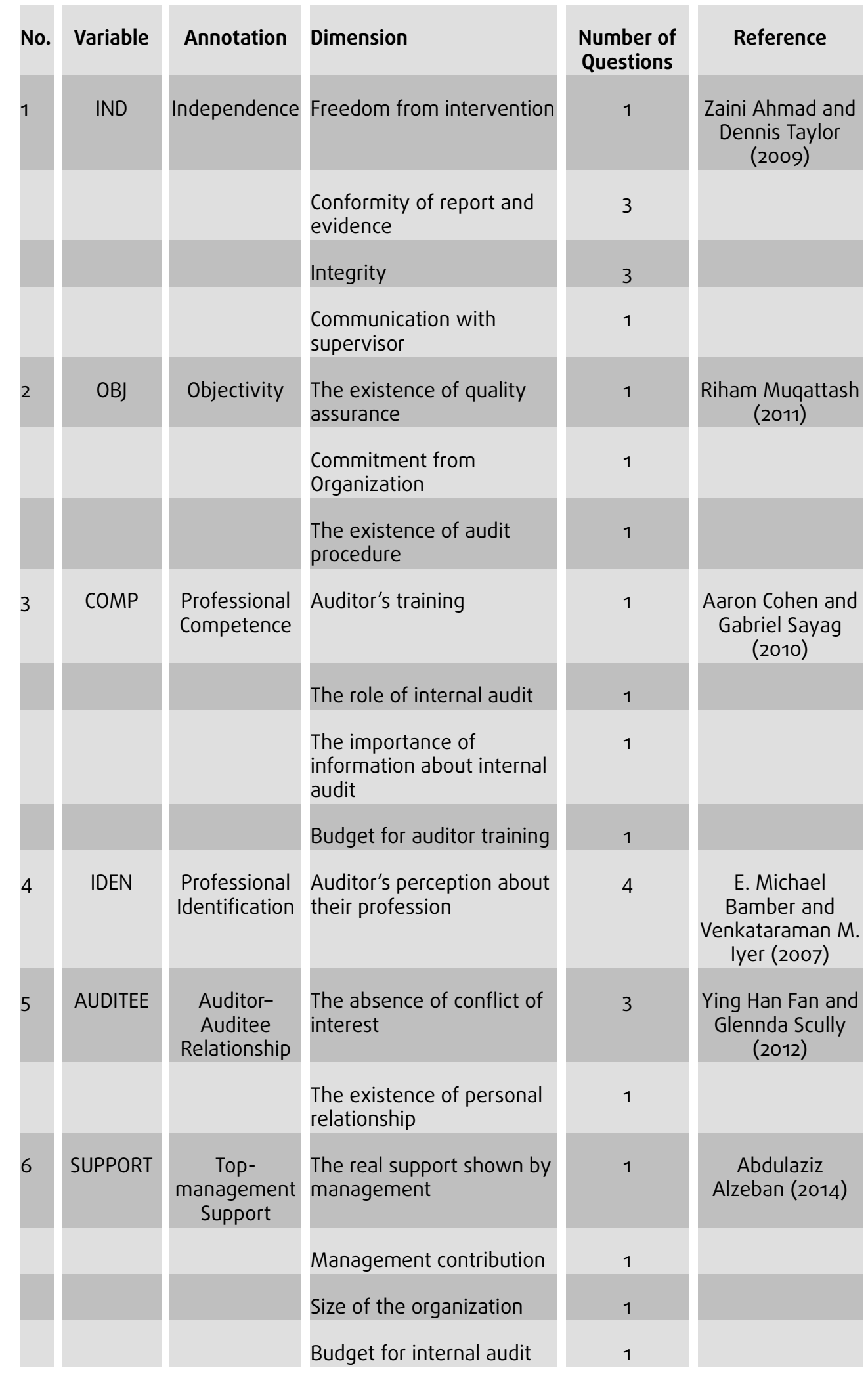

COMP = Professional Competence

PROFIDENT $=$ Professional Identification 


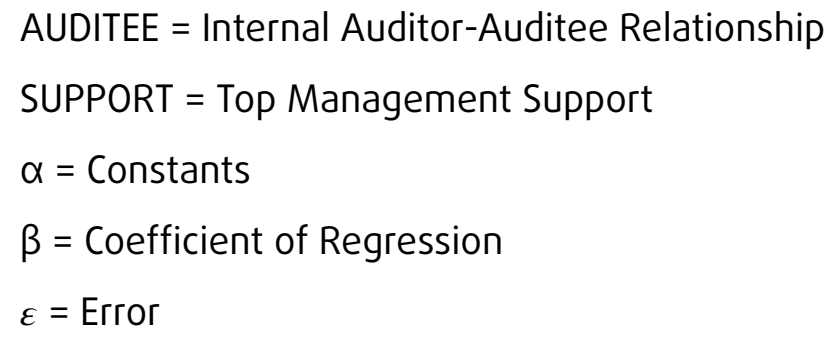

\section{Findings}

\subsection{Validity and reliability test}

A validity check has been conducted to test whether each item of the questionnaire is relevant. Based on the validity test that we have conducted, all items of questions in the questionnaires have R-statistic greater than the R-table. It means that all of the questions are relevant to explain the variables we use in this research. Furthermore, reliability check is performed to test whether the questionnaire is reliable for conducting the research. Based on the reliability test, we get R-statistic for each variable ranging from 0.992 to 0.999 , and the $R$ value we get from the table is 0.284 . It means that all variables are reliable to conduct this research.

\subsection{Descriptive analysis and correlation}

To know the mean, minimum and maximum value, and the standard deviation of the data for each variable, descriptive statistic is conducted. The summary for the descriptive statistic results can be seen in Table 3.

From Table 3, it can be seen that the amount of respondents volunteering in this research is 204 individual $(N=204)$. The minimum values for each variable, independence, objectivity, competence, auditor-auditee relationship, professional identification and top-management support sequentially, are: $2.5,2,1.5,2.25,2,1.75$. On the other hand, the maximum value for all of those variables is 4 . From the calculation of the data, it can be known that the mean values for each of those variables sequentially are $3.28,3.34,3.19,3.31,2.72$ and 3.05 .

The correlation test is conducted by using Pearson Correlation. As seen in Table 4, the relationship among variables is strong and linear, because the value of the correlation is close to 1. The significant value less than 0.05 shows the existence of significant relationship between independent variable and dependent variable in the research. 
TABLE 3: Descriptive statistics and correlation.

\begin{tabular}{|c|c|c|c|c|c|c|c|}
\hline & IND & OBJ & COMP & IDEN & AUDITEE & EXTERN & SUPPORT \\
\hline MIN & 2 & 2 & 1.5 & 2 & 2.25 & 1.75 & 1.75 \\
\hline MAX & 4 & 4 & 4 & 4 & 4 & 4 & 4 \\
\hline MEAN & 3.280 & 3.339 & 3.191 & 2.720 & 3.313 & 2.848 & 3.046 \\
\hline STD & 0.353 & 0.525 & 0.490 & 0.425 & 0.420 & 0.448 & 0.508 \\
\hline OBJ & & 1.000 & & & & & \\
\hline IND & 1.000 & & & & & & \\
\hline \multirow[t]{2}{*}{ COMP } & $0.435^{a}$ & $0.681^{a}$ & 1.000 & & & & \\
\hline & 0.000 & 0.000 & & & & & \\
\hline \multirow[t]{2}{*}{ IDEN } & $0.102^{c}$ & $0.195^{a}$ & $0.177^{a}$ & 1.000 & & & \\
\hline & 0.073 & 0.003 & 0.006 & & & & \\
\hline \multirow[t]{2}{*}{ AUDITEE } & $0.434^{a}$ & $0.552^{a}$ & $0.442^{a}$ & $0.096^{c}$ & 1.000 & & \\
\hline & 0.000 & 0.000 & 0.000 & 0.085 & & & \\
\hline \multirow[t]{2}{*}{ SUPPORT } & $0.273^{a}$ & $0.596^{a}$ & $0.686^{a}$ & $0.237^{a}$ & $0.473^{a}$ & $0.315^{a}$ & 1.000 \\
\hline & 0.000 & 0.000 & 0.000 & 0.000 & 0.000 & 0.000 & \\
\hline \multicolumn{8}{|c|}{ Note: IND = Independence, OBJ = Objectivity, $C O M P$ = Professional Competence, } \\
\hline \multicolumn{8}{|c|}{ IDEN = Professional Identification, AUDITEE = Internal Auditor-Auditee Relationship, } \\
\hline \multicolumn{8}{|c|}{ SUPPORT = Top-management Support } \\
\hline \multicolumn{8}{|c|}{${ }^{a}$ significance level = 0.01} \\
\hline${ }^{b}$ significan & $\mathrm{vel}=0 . \mathrm{c}$ & & & & & & \\
\hline
\end{tabular}

\subsection{Multivariate linear regression}

Coefficient of regression for professional competence has a positive value of 0.283 or 28.3 percent for independence and 0.491 for objectivity and has a significance value of 0.000 for both independence and objectivity. It means that the professional competence positively affects the internal auditors' independence, so an increase in professional competence will improve internal auditors' independence.

Professional identification has a negative value of coefficient of regression of 0.032 with a significance 0.532 for independence, and for objectivity, the value of coefficient 
TABLE 4: Multivariate linear regression.

\begin{tabular}{|c|c|c|c|c|c|}
\hline \multirow[t]{2}{*}{ Model } & \multirow[b]{2}{*}{ Sign } & \multicolumn{2}{|c|}{ Independence } & \multicolumn{2}{|c|}{ Objectivity } \\
\hline & & Coef. & $P$-value & Coef. & $P$-Value \\
\hline Constant & positive & 1.706 & 0.000 & 0.107 & 0.675 \\
\hline COMP & positive & 0.283 & 0.000 & 0.491 & 0.000 \\
\hline PROFIDENT & positive & 0.032 & 0.532 & 0.067 & 0.274 \\
\hline AUDITEE & positive & 0.281 & 0.000 & 0.301 & 0.000 \\
\hline SUPPORT & positive & -0.113 & 0.062 & 0.159 & 0.027 \\
\hline F Value & 15.633 & & & 47.224 & \\
\hline Sig. & 0.000 & & & 0.000 & \\
\hline $\mathrm{R}^{2}$ & 0.275 & & & 0.541 & \\
\hline Adj. $R$ & 0.261 & & & 0.531 & \\
\hline \multicolumn{6}{|c|}{ Note: IND = Independence, OBJ = Objectivity, COMP = Professional Competence, } \\
\hline
\end{tabular}

of regression is 0.067 with significance of 0.274 . It means that the professional identification neither affects the independence nor the objectivity of internal auditors in Indonesian government entities.

Coefficient of regression for auditor-auditee relationship is 0.281 (sig. 0.000) for independence and 0.301 (sig. 0.000) for objectivity. It means that the relationship of internal auditor and auditee affects positively both the independence and objectivity.

The coefficient of regression for top-management support is -0.113 (sig. 0.062) for independence and 0.159 (sig. 0.027) for objectivity. It means that top-management support does not affect independence but affects objectivity of internal auditor.

\subsection{Additional findings}

The variables that have significant effects toward internal auditor's independence are professional competence and auditor-auditee relationship. Professional competence has coefficient of correlation of 0.310 with a significance value of 0.000 , whereas auditor-auditee relationship has a coefficient correlation of 0.255 with significance value of 0.001 . Variables other than professional competence and auditor-auditee relationship have no significant effect toward internal auditor's independence. It means 
TABLE 5: Linear regression per institution.

\begin{tabular}{|c|c|c|c|c|c|c|c|c|c|}
\hline \multirow[t]{3}{*}{ Model } & \multicolumn{5}{|c|}{ Ministry of Finance } & \multicolumn{4}{|c|}{ Ministry of Religious Affairs } \\
\hline & \multicolumn{3}{|c|}{ Independence } & \multicolumn{2}{|c|}{ Objectivity } & \multicolumn{2}{|c|}{ Independence } & \multicolumn{2}{|c|}{ Objectivity } \\
\hline & Sign & Coef. & $P$-value & Coef. & $P$-Value & Coef. & $P$-value & Coef. & $P$-value \\
\hline Constant & + & 2.165 & 0.000 & 0.398 & 0.205 & 1.166 & 0.059 & 0.902 & 0.141 \\
\hline COMP & + & 0.310 & 0.000 & 0.383 & 0.000 & 0.155 & 0.224 & 0.553 & 0.000 \\
\hline PROFIDENT & + & -0.018 & 0.767 & 0.036 & 0.610 & 0.164 & 0.253 & 0.101 & 0.479 \\
\hline AUDITEE & + & 0.255 & 0.001 & 0.436 & 0.000 & 0.235 & 0.015 & 0.016 & 0.869 \\
\hline SUPPORT & + & -0.183 & 0.018 & 0.070 & 0.429 & 0.111 & 0.356 & 0.284 & 0.021 \\
\hline F value & & 8.997 & & 26.154 & & 5.488 & & 24.732 & \\
\hline Sig. & & 0.000 & & 0.000 & & & & & 0.000 \\
\hline $\mathrm{R}^{2}$ & & 0.254 & & 0.498 & & & & & 0.673 \\
\hline Adj. $R^{2}$ & & 0.226 & & 0.479 & & & & & 0.646 \\
\hline No & pend & ( & his & $\mathrm{COI}$ & Prof & nal C & tence, & & \\
\hline
\end{tabular}

that the increase in professional competence and/or the increase in the quality of relationship between internal auditor and auditee will increase the independence of internal auditor in the Ministry of Finance.

From Table 5, it can be found that only professional competence and auditorauditee relationship have significant value toward objectivity of the internal auditor. The coefficient correlation for professional competence is 0.383 with a significance value of 0.000 , and for auditor-auditee relationship, the coefficient correlation is 0.436 with a significance effect of 0.000 . Variables other than professional competence and auditor-auditee relationship have no significant effect toward objectivity. In other words, the increase of professional competence and/or the increase of relationship quality between internal auditor and their auditee will improve the objectivity of internal auditor in the Ministry of Finance.

From Table 5, it can be found that the only variable that has a significant effect toward independence of internal auditor in Ministry of Religious Affairs is auditorauditee relationship with a coefficient correlation of 0.235 and a significance value of 0.015. All of the other variables do not affect the independence of an internal auditor. Auditor-auditee relationship has a positive effect, in other words, the better the quality 
of relationship between internal auditor and their auditee, the more improved the independence of internal auditor in the Ministry of Religious Affairs.

Hence, it can be concluded from Table 5 that there are three variables that affect the objectivity of internal auditors in the Ministry of Religious Affairs, which are professional competence and top-management support. Auditor-auditee relationship and professional identification do not affect objectivity significantly. Professional competence has a coefficient correlation of 0.553 and a significance value of 0.000 , it means that the more the competence of an auditor, the more objective he/she is. Top-management support has a coefficient correlation of 0.284 with a significance value of 0.021 , it means that top-management support has a positive effect toward internal auditors' objectivity in the Ministry of Religious Affairs. In other words, the higher the support from the top management, the more objective the internal auditors will be.

\section{Discussion}

The result shows that institution where the internal auditors work has a significant effect toward both independence and objectivity. The Ministry of Finance as the Chief Financial Officer also plays as a role model for other government entities. Because their job is to manage the state's financial resources, it is understood that the human resource inputs for the Ministry of Finance is higher than that of the Ministry of Religious Affairs. The selection is more difficult, more complicated, and they even have a special college to provide the needs for qualified human resource. Hence, the higher the quality of the auditor, the better they understand independence and objectivity and the importance of them.

Furthermore, the Ministry of Finance and the Ministry of Religious Affairs have a different culture, even though they work for the same organization. The Ministry of Finance is known to be more professional, has more integrity about their job and is more efficient. As for their role as CFO, they need to be the example of a good governance, particularly in financial management.

In general, professional competence positively affects both the independence and the objectivity of internal auditors. This finding supports the study of Alzeban (2014) and Ma'ayan and Carmeli (2015), but it contrast to the findings of Cohen and Sayag (2010) who say that professional competence has no effect toward internal auditors' effectiveness. An auditor is said to be competent in their field when they have sufficient education, training and/or experience in the auditing field. The more they are 
educated or experienced, the more they know and understand the values of auditors and the importance of them, which are independence and objectivity.

The finding shows that professional identification affects neither the independence nor the objectivity. It is in contrast to what Bamber and Iyer (2007) have found, who mention that professional identification has a significant effect toward auditors' objectivity. The research conducted by Bamber and Iyer (2007) uses external auditors as the object, whereas this research uses internal auditor as the object. It can be one reason why the two researches show different and contrasting results. Internal auditors work for their organizations, their clients are also from the same organization and they are paid by their organizations. All of the internal auditors in government organizations are public servant, which has stereotype of 'however good your work is, you will be paid the same'. With mindset like that, pride about the professional title is not one of the public servant's strong suit.

The hypotheses about auditor-auditee relationship that affect the independence and objectivity are both accepted. It is supported by the study result of Fan, Woodbine and Scully (2012), but it is contrasting to the result of Ball and Tyler (2015). The quality of relationship between internal auditor and auditee undoubtedly plays a significant role toward their independence, both in appearance and in fact. When an internal auditor is known to have a conflict of interest with their auditee, either they have close a relationship or they are given material facilities or gratification, the objectivity of their audit work is being questioned. Ball and Tyler (2007) indeed mention that auditorauditee relationship affects negatively the audit quality. However, the definition of auditor-auditee relationship in their research is different from the definition of the same variable in this research. They define the auditor-auditee relationship as the time period the auditor-auditee have been working together. In this research, the author defines internal auditor-auditee relationship as the state of professional relationship between internal auditor and auditee where there is no conflict of interest between them.

However, the special case is that the professional competence does not affect the independence of internal auditors in the Ministry of Religious Affairs. It can indicate as a good or a bad thing. In a good case, internal auditors would understand the importance of independence regardless their level of competence, so whether they are competent or not, they will keep their independence in mind and in appearance. In the bad case, they do not understand the importance of independence by heart, so the increasing of knowledge they got from formal education or experience does not improve their independence from time to time. 
Top-management support affects internal auditors' objectivity but does not affect the independence in general. However, in the Ministry of Finance, it affects the independence, whereas in the Ministry of Religious Affairs, it only affects the objectivity. Generally, the support from the management will improve the quality of audit and the auditors. It is supported by the findings from the studies of Cohen and Sayag (2010), Alzeban (2014) and Ma'ayam and Carmeli (2015) that show the positive effect of topmanagement support toward internal auditors' effectiveness.

Top management is the party who hires and pays the internal auditor to work in the organization. Therefore, there is a gratitude attitude in internal auditors toward the top management. It is difficult to be independent in appearance for internal auditor because their client is their organization itself and the leaders are the same top management. Hence, the more support from the top management will not improve the independence of internal auditors.

Support from the top management could be in the form of sufficient facilities and budget, attention given toward internal auditors' activity, or involvement of the top management in the internal audit work. Sufficient budget means higher chance of training, it also means that auditor's capacity improves over time. The improvement of auditor's capacity could lead to the improvement of independence and objectivity. However, the effect is rather different in the Ministry of Finance and the Ministry of Religious Affairs. In the Ministry of Finance, it only affects their independence, whereas in the Ministry of Religious Affairs, it affects the objectivity.

\section{Conclusion}

This research has a purpose to examine the determinant factors affecting the independence and the objectivity in Indonesian government entities. The result shows that the professional competence and internal auditor-auditee relationship are the two key factors that affect both the independence and objectivity. Both of the variables positively affect the independence and objectivity.

This research has some limitations in the process; first, the author could not control the respondents because of time and distance limitation. There is a possibility of bias due to this condition that can be caused by the misunderstanding of the questions in the questionnaire. There are a few responses that do not correspond to the context that the author has to eliminate the responses. It is possible that the factors behind this case is because not all respondents understand the meaning of the questions. The questions in the questionnaire are adopted from international journal that possibly has 
different circumstances from Indonesia, it can increase the risk of misunderstanding and biasness.

\section{References}

[1] Abdul Wahab, E. A., Mat Zain, M., \& Abdul Rahman, R. (2015). Political connections: a threat to auditor independence? Journal of Accounting in Emerging Economies, $5(2), 222-246$

[2] Alexander, D., \& Hay, D. (2013). The effects of recurring and non-recurring non-audit services on auditor independence. Managerial auditing journal, 28(5), 407-425.

[3] Al-Twaijry, A. A., Brierley, J. A., \& Gwilliam, D. R. (2003). The development of internal audit in Saudi Arabia: an institutional theory perspective. Critical Perspectives on Accounting, 14(5), 507-531.

[4] Alzeban, A., \& Gwilliam, D. (2014). Factors affecting the internal audit effectiveness: A survey of the Saudi public sector. Journal of International Accounting, Auditing and Taxation, 23(2), 74-86.

[5] Arens, A. A., Elder, R. J., \& Mark, B. (2012). Auditing and assurance services: an integrated approach: Boston: Prentice Hall.

[6] Ball, F., Tyler, J., \& Wells, P. (2015). Is audit quality impacted by auditor relationships? Journal of Contemporary Accounting \& Economics, 11(2), 166-181.

[7] Bamber, E. M., \& Iyer, V. M. (2007). Auditors' identification with their clients and its effect on auditors' objectivity. Auditing: A Journal of Practice \& Theory, 26(2), 1-24.

[8] Brierley, J. A., El-Nafabi, H. M., \& Gwilliam, D. R. (2002). Accounting and auditing requirements of the Sudan Companies Act 1925: time for change. Managerial auditing journal, 17(3), 113-116.

[9] Brody, R. G., \& Lowe, D. J. (2000). The new role of the internal auditor: Implications for internal auditor objectivity. International Journal of Auditing, 4(2), 169-176.

[10] Cameran, M. (2005). The audit firm rotation rule: A review of the literature. Bocconi University.

[11] Cohen, A., \& Sayag, G. (2010). The effectiveness of internal auditing: an empirical examination of its determinants in Israeli organisations. Australian Accounting Review, 20(3), 296-307.

[12] Committee, A. I. 0. C. P. A. A. S. E. (2006). Codification of Statements on Auditing Standards: Commerce Clearing House.

[13] DeAngelo, L. E. (1981). Auditor size and audit quality. Journal of accounting and economics, 3(3), 183-199. 
[14] Deis Jr, D. R., \& Giroux, G. A. (1992). Determinants of audit quality in the public sector. Accounting Review, 462-479.

[15] Ghozali, I. (2011). Aplikasi Analisis Multivariate dengan Program IBM SPSS 19-5/E.

[16] Goodwin, J., \& Yeo, T. Y. (2001). Two factors affecting internal audit independence and objectivity: Evidence from Singapore. International Journal of Auditing, 5(2), 107-125.

[17] Han Fan, Y., Woodbine, G., \& Scully, G. (2012). Chinese auditors' views about independence and employer values. Asian Review of Accounting, 20(1), 74-87.

[18] Hudaib, M., \& Haniffa, R. (2009). Exploring auditor independence: an interpretive approach. Accounting, Auditing \& Accountability Journal, 22(2), 221-246.

[19] Indonesia, A. A. I. P. (2013). Standar Audit Intern Pemerintah Indonesia. Jakarta: Komite Standar Audit AAIPI.

[20] Irmawan, Y., Hudaib, M., \& Haniffa, R. (2013). Exploring the perceptions of auditor independence in Indonesia. Journal of Islamic Accounting and Business Research, $4(2), 173-202$.

[21] Johnstone, K. M., Warfield, T. D., \& Sutton, M. H. (2001). Antecedents and consequences of independence risk: Framework for analysis. Accounting Horizons, $15(1), 1-18$.

[22] Krambia Kapardis, M., \& Romero, S. (2010). Auditor independence: third party hiring and paying auditors. EuroMed Journal of Business, 5(3), 298-314.

[23] Lindberg, D. L., \& Beck, F. D. (2004). Before and after Enron: CPAs' views on auditor independence. The CPA Journal, 74(11), 36.

[24] Loi, R., Hang-Yue, N., \& Foley, S. (2004). The effect of professional identification on job attitudes: A study of lawyers in Hong Kong. Organizational Analysis, 12(2), 109-128.

[25] Ma'Ayan, Y., \& Carmeli, A. (2016). Internal Audits as a Source of Ethical Behavior, Efficiency, and Effectiveness in Work Units. Journal of Business Ethics, 137(2), 347363.

[26] Mael, F., \& Ashforth, B. E. (1992). Alumni and their alma mater: A partial test of the reformulated model of organizational identification. Journal of organizational Behavior, 13(2), 103-123.

[27] Mohamed, D. M., \& Habib, M. H. (2013). Auditor independence, audit quality and the mandatory auditor rotation in Egypt. Education, Business and Society: Contemporary Middle Eastern Issues, 6(2), 116-144. 
[28] Mutchler, J. F. (2003). Independence and objectivity: a framework for research opportunities in internal auditing. Research Opportunities in Internal Auditing, 231268.

[29] Raiborn, C., Schorg, C. A., \& Massoud, M. (2006). Should auditor rotation be mandatory? Journal of Corporate Accounting and Finance, 17(4), 37.

[30] Reynolds, J. K., Deis Jr, D. R., \& Francis, J. R. (2004). Professional service fees and auditor objectivity. Auditing: A Journal of Practice \& Theory, 23(1), 29-52.

[31] Sekaran, U., \& Bougie, R. (2013). Research methods for business: A skill-building approach.[e-book]: Wiley \& Sons. http://www.wiley.com/college.

[32] Stewart, J., \& Subramaniam, N. (2010). Internal audit independence and objectivity: emerging research opportunities. Managerial auditing journal, 25(4), 328-360. 